\title{
Characterisation of three novel CYP11B1 mutations in classic and non-classic 11ß-hydroxylase deficiency
}

\author{
Seher Polat, Alexandra Kulle', Züleyha Karaca ${ }^{2}$, Ilker Akkurt' ${ }^{3}$, Selim Kurtoglu ${ }^{4}$, \\ Fahrettin Kelestimur ${ }^{2}$, Joachim Grötzinger ${ }^{5}$, Paul-Martin Holterhus ${ }^{1}$ and \\ Felix G Riepe ${ }^{1}$
}

Department of Medical Genetics, Erciyes University, Kayseri, Turkey, 'Division of Pediatric Endocrinology and Diabetes, Department of Pediatrics, University Hospital Schleswig-Holstein, Christian-Albrechts-University Kiel, Schwanenweg 20, D-24105 Kiel, Germany, ${ }^{2}$ Department of Endocrinology, Erciyes University, Kayseri, Turkey, ${ }^{3}$ Childrens Hospital Altona, Pediatric Endocrinology, Hamburg, Germany, ${ }^{4}$ Department of Pediatric Endocrinology, Erciyes University, Kayseri, Turkey and ${ }^{5}$ Institute of Biochemistry, Christian-Albrechts-University Kiel, Kiel, Germany
Correspondence should be addressed to F G Riepe

Email

friepe@pediatrics.uni-kiel.de

\begin{abstract}
Background: Congenital adrenal hyperplasia (CAH) is one of the most common autosomal recessive inherited endocrine diseases. Steroid 11 $\beta$-hydroxylase (P450C11) deficiency (11OHD) is the second most common form of CAH. Aim: The aim of the study was to study the functional consequences of three novel CYP11B1 gene mutations (p.His125Thrfs*8, p.Leu463_Leu464dup and p.Ser150Leu) detected in patients suffering from 11OHD and to correlate this data with the clinical phenotype.

Methods: Functional analyses were done by using a HEK293 cell in vitro expression system comparing WT with mutant P450c11 activity. Mutant proteins were examined in silico to study their effect on the three-dimensional structure of the protein.

Results: Two mutations (p.His125Thrfs*8 and p.Leu463_Leu464dup) detected in patients with classic 110HD showed a complete loss of P450c11 activity. The mutation (p.Ser150Leu) detected in a patient with non-classic 110HD showed partial functional impairment with $19 \%$ of WT activity.

Conclusion: Functional mutation analysis enables the correlation of novel CYP11B1 mutations to the classic and non-classic $110 \mathrm{HD}$ phenotype respectively. Mutations causing a non-classic phenotype show typically partial impairment due to reduced maximum reaction velocity comparable with non-classic mutations in 21-hydroxylase deficiency. The increasing number of mutations associated with non-classic 110HD illustrate that this disease should be considered as diagnosis in patients with otherwise unexplained hyperandrogenism.
\end{abstract}

\section{Introduction}

Congenital adrenal hyperplasia $(\mathrm{CAH})$, one of the most common autosomal recessive inherited endocrine diseases, is characterised by complete or partial impairment of adrenal steroidogenesis $(1,2)$. Although over $90 \%$ of cases of $\mathrm{CAH}$ are caused by 21 -hydroxylase deficiency, steroid 11ß-hydroxylase (P450c11, EC 1.14.15.4) deficiency (11OHD) accounts for $5-8 \%$ of cases, reflecting a frequency of $\sim 1: 100000-1: 200000$ live births in non-consanguineous populations $(3,4,5)$.

The 11ß-hydroxylase belongs to the cytochrome P450 system (P450c11) that facilitates the conversion of 11-deoxycortisol (S) to cortisol (F) and 11-deoxycorticosterone (DOC) to corticosterone (B) in the mitochondria of the adrenal cortex. 11OHD is characterised by deficient
(ㄷ) 2014 European Society of Endocrinology Printed in Great Britain
Published by Bioscientifica Ltd. 
cortisol synthesis caused by mutations in the CYP11B1 gene coding for $11 \beta$-hydroxylase $(6,7,8,9)$. An impairment of $11 \beta$-hydroxylase activity leads to an accumulation of the precursor steroids, which are shunted into the adrenal androgen synthesis pathway, resulting in prenatal virilisation of female external genitalia (46,XX disorder of sex development). Moreover, the excess of postnatal androgen causes androgenisation and rapid somatic growth as well as accelerated bone maturation in both sexes. The accumulation of DOC, which binds to and activates the mineralocorticoid receptor, leads to hypertension in about two-thirds of all patients $(3,10,11,12$, 13). Hormonal diagnosis of $110 H D$ is verified by elevated baseline concentrations of DOC and S in classical forms as well as increased response to cosyntropin stimulation in non-classic forms (14).

The non-classic 11OHD form is caused by partial impairment of the P450c11 function $(10,15)$ with a phenotype resembling non-classic 21-hydroxylase deficiency (11). Non-classic 11OHD can manifest with mild virilisation and precocious pseudopuberty in children. Female patients with non-classic 110 HD are born with normal external genitalia and may have hirsutism and oligomenorrhea in adulthood, resembling signs and symptoms suggestive for polycystic ovary syndrome. However, only a minor percentage of women with hirsutism and oligomenorrhea suffer from non-classic
11OHD (10). Unlike in classic 11OHD, arterial hypertension is not commonly found.

In the current study, three novel CYP11B1 mutations detected in three patients with classic and in one patient with non-classic 11 OHD were studied in order to describe the effect of these variants.

\section{Subjects and methods}

\section{Patient 1}

A male patient (karyotype 46,XY) of Turkish origin was referred to the Paediatric Endocrinology Department at Erciyes University, Kayseri, Turkey at the age of 2 years with the complaint of penile growth. His parents are first cousins and he has three siblings, one of them also suffering from 11OHD (patient 2). Results of the initial physical examination were as follows: height $97 \mathrm{~cm}$ (+3.1 SDS) (16), weight $17 \mathrm{~kg}$, BMI $18 \mathrm{~kg} / \mathrm{m}^{2}$ (+1.07 SDS) (17), blood pressure 100/70 $\mathrm{mmHg}$ (90th percentile) (18), testicular volume $3 \mathrm{ml}$, penile length $9 \mathrm{~cm}$ (+5.3 SDS) (19), advanced bone age of 7 years and dark skin pigmentation especially at the genitalia. Abdominal ultrasound examination revealed hyperplasic adrenal glands. Steroid hormone analyses supported the diagnosis of 11OHD (Table 1). Hydrocortisone supplementation was initiated. During his last visit at 14 years of age, physical examination revealed the

Table 1 Laboratory data before treatment.

\begin{tabular}{|c|c|c|c|c|}
\hline & Patient 1 & Patient 2 & Patient 3 & Patient 4 \\
\hline Karyotype & $46, X Y$ & $46, x X$ & $46, X Y$ & $46, X X$ \\
\hline Genotype & $\begin{array}{l}\text { p.His125Thrfs*8/ } \\
\text { p.His125Thrfs*8 }\end{array}$ & $\begin{array}{l}\text { p.His125Thrfs*8/ } \\
\text { p.His125Thrfs*8 }\end{array}$ & $\begin{array}{l}\text { p.Leu463_Leu464dup/ } \\
\text { p.Leu463_Leu464dup }\end{array}$ & $\begin{array}{l}\text { p.His125Thrfs*8/ } \\
\text { p.Ser150Leu }\end{array}$ \\
\hline Age at analysis & 2 years & 2 days & 26 years & 5 years \\
\hline $\begin{array}{l}\text { 11-Deoxycorticosterone } \\
\text { (ng/ml) }\end{array}$ & ND & ND & ND & $1.0 \rightarrow 11.5$ (bl. 0.06-0.52) \\
\hline Corticosterone (ng/ml) & ND & ND & ND & $1.4 \rightarrow 22.5$ (bl. 0.09-1.46) \\
\hline Aldosterone (pg/ml) & ND & $258(70-540)$ & $16.7(35-300)$ & ND \\
\hline 17-OHP (ng/ml) & $17.56(0.6-3.4)$ & $48.73(0.6-3.4)$ & $4.2(0.6-3.4)$ & $0.40 \rightarrow 1.9$ (bl. 0.06-0.56) \\
\hline 11-Deoxycortisol (ng/ml) & $60.35(0.1-14)$ & $31.94(0.1-14)$ & $46.6(0-8)$ & $4.92 \rightarrow 30.9$ (bl. 0.09-1.11) \\
\hline Cortisol $(\mu \mathrm{g} / \mathrm{dl})$ & $38^{\mathrm{a}}(5-26)$ & $73.7^{a}(5-26)$ & $2.2(5-26)$ & $\begin{aligned} 90 & \rightarrow 158 \text { (bl. } 5.62-170.28 \\
& \text { and stim. }>150)\end{aligned}$ \\
\hline DHEA-S (ng/ml) & $532(50-480)$ & $4692(50-480)$ & $7527(300-3330)$ & ND \\
\hline $\begin{array}{l}\text { Androstenedione } \\
(\mathrm{ng} / \mathrm{ml})\end{array}$ & $23.66(0.08-0.5)$ & $70.10(0.2-2.9)$ & ND & $109 \rightarrow 97$ (bl. 2.9-43) \\
\hline $\begin{array}{l}\text { Total testosterone } \\
\text { (ng/dl) }\end{array}$ & $657(3-10)$ & $4355(20-64)$ & $492(11-80)$ & $26 \rightarrow 34$ (bl. 2.9-20) \\
\hline $\operatorname{Renin}(\mathrm{pg} / \mathrm{ml})$ & ND & $0.76(1.9-6.0)$ & $0.89(1.9-6.0)$ & ND \\
\hline ACTH $(\mathrm{pg} / \mathrm{ml})$ & $2690(5-60)$ & $1540(5-60)$ & $4328(5-60)$ & ND \\
\hline
\end{tabular}

Reference ranges in brackets (bl., baseline and stim., stimulated), ND, not done. Steroids in the patients 1, 2 and 3 have been detected by RIA. ${ }^{a}$ The cortisol RIA (ICN Biomedicals, Inc., Irvine, CA, USA, 1999) assay used in patients 1 and 2 has a 33\% cross-reactivity with 11-deoxycortisol causing elevated cortisol concentrations in the case of 110 HD. Steroids in the patient 4 have been detected by LC-MSMS ( 56 ) before and 60 min after $250 \mu \mathrm{g}$ ACTH i.v. 
following: height $169 \mathrm{~cm}$ (0.1 SDS) (20), weight $59 \mathrm{~kg}$, BMI $20 \mathrm{~kg} / \mathrm{m}^{2}$ (+0.37 SDS) (17), blood pressure 110/70 $\mathrm{mmHg}$ (50th percentile) (17), bilateral testicular volume $25 \mathrm{ml}$, pubic hair Tanner stage 5 , stretched penile length $13 \mathrm{~cm}$ (+0.0 SDS) (18) and a bone age of 16 years. Although he was advised to take up $20 \mathrm{mg} / \mathrm{m}^{2}$ per day hydrocortisone by the general practitioner, the laboratory investigations revealed insufficient control of the disease due to nonadherence to the therapy (DOC $215.81 \mathrm{ng} / \mathrm{ml}$ (reference range (0.12-1.58), DHEAS $981 \mathrm{ng} / \mathrm{ml}$ (1200-3700), total testosterone $882 \mathrm{ng} / \mathrm{dl}$ (350-970) and androstenedione $9.42 \mathrm{ng} / \mathrm{ml}(0.33-1.9))$.

\section{Patient 2}

The female patient (karyotype 46,XX) was born after an uneventful pregnancy (height at birth $50 \mathrm{~cm}$, weight $3400 \mathrm{~g}$ ). She is the younger sister of patient 1 . She was referred at the age of 2 days to the Paediatric Endocrinology Department at Erciyes University, Kayseri, Turkey because of ambiguous genitalia. She had virilised external genitalia reflecting Prader stage 3 without obvious hyperpigmentation of the skin. Pelvic ultrasonography revealed a small uterus, cervix and vagina. Steroid hormone analyses confirmed the diagnosis of 110 HD (Table 1). Hydrocortisone treatment was initiated. At her last visit to the Paediatric Endocrinology Department at the age of 12.5 years, the physical examination results were weight $42 \mathrm{~kg}$ (-0.1 SDS), height $145 \mathrm{~cm}(-1.04 \mathrm{SDS})$ (20), BMI $20 \mathrm{~kg} / \mathrm{m}^{2}$ (+0.17 SDS) (21), blood pressure 90/50 $\mathrm{mmHg}$ (10th percentile) (18), pubic hair and breast development Tanner stage 3 and bone age of 14 years. The patient was only irregularly followed up and adhered poorly to the treatment with hydrocortisone, which was increased up to $20 \mathrm{mg} / \mathrm{m}^{2}$ per day by the general practitioner. Hormone analyses showed insufficient therapy (DOC $281 \mathrm{ng} / \mathrm{ml}$ (reference range 0.12-1.58), DHEAS $482 \mathrm{ng} / \mathrm{ml}$ (320-2260), total testosterone $269 \mathrm{ng} / \mathrm{dl}$ (15-35) and androstenedione $7 \mathrm{ng} / \mathrm{ml}(0.5-1.7))$.

\section{Patient 3}

A 27-year-old male patient (karyotype 46,XY) of Turkish ancestry was referred to the Endocrinology Department at Erciyes University, Kayseri, Turkey with the complaint of infertility (Table 1). Premature pubarche led to clinical work up in infancy and revealed 110HD. Hormonal data from that time are not available. Treatment with hydrocortisone was initiated at that time, but then he was lost to follow-up until the age of 27 years. At that time, his height and weight were $152 \mathrm{~cm}(-3.41$ SDS) (20) and $65 \mathrm{~kg}$, respectively, and his BMI was $28 \mathrm{~kg} / \mathrm{m}^{2}$ (+0.11 SDS) (17). Hormonal data at 27 years of age is shown in Table 1. Blood pressure was not taken on that occasion. Computed tomography scan of adrenal glands revealed nodular thickening. Semen analysis revealed severe oligospermia and mild-to-moderate asthenozoospermia. Folliclestimulating hormone and luteinising hormone levels were elevated with $17 \mathrm{mIU} / \mathrm{ml}$ (reference range 1.5-12.4) and $10 \mathrm{mIU} / \mathrm{ml}$ (1.7-8.6) respectively. Scrotal ultrasonography revealed two heterogeneous hypoechogenic lesions (right testis, $38 \times 20 \mathrm{~mm}$ and left testis, $24 \times$ $155 \mathrm{~mm}$ ) with lobulated contours and irregular boundaries reflecting testicular adrenal rest tumours (TART). The TART located on right testis was removed by testis sparing surgery. Histological examination was compatible with TART (Fig. 1). Prednisolone therapy was resumed and the patient's wife gave birth to a female child. The patient's fertility was not investigated in detail as he refused to perform a semen analysis.

\section{Patient 4}

The female patient (karyotype 46,XX) of Moroccan descent was diagnosed at the Paediatric Endocrinology unit at the Children's Hospital Altona, Hamburg, Germany, as non-classical 11OHD when she was 5.5 years old and came to attention with premature

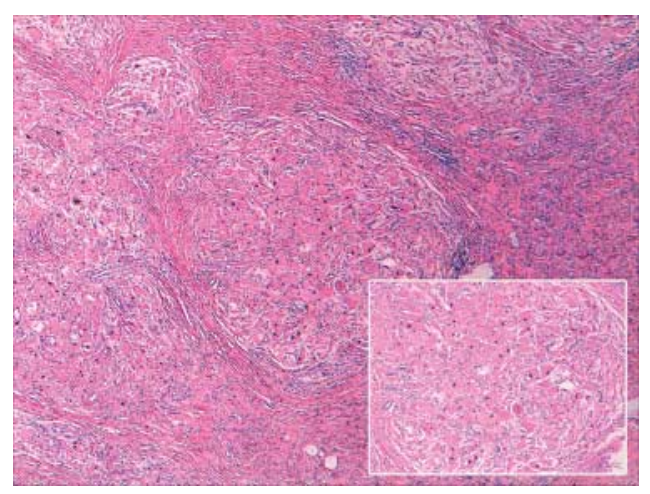

\section{Figure 1}

Histopathology from frozen tissue section of TART (magnification $\times 40$ ). Multiple nodules are present having an appearance comparable with adrenal origin. The lesion was composed of sheets and nests separated by fibrous tissue. The individual cells were large, round with round nuclei with defined borders and abundant eosinophilic cytoplasm (cutout, magnification $\times 100$ ). 
pubarche without further signs of virilisation. Clinical characteristics at diagnosis were height $112,2 \mathrm{~cm}(-0.7$ SDS) (20), growth rate $10.7 \mathrm{~cm} /$ year $(+5.2 \mathrm{SDS})$, weight $21.3 \mathrm{~kg}, \mathrm{BMI} 16.9 \mathrm{~kg} / \mathrm{m}^{2}$ (0.86 SDS) (17) and bone age of 8.5 years. Ultrasonography of the ovaries and adrenals revealed no pathological changes. Baseline DOC and S were elevated and cortisol was within the reference range (Table 1). ACTH stimulation test showed significantly increased response of DOC and $\mathrm{S}$ with sufficient rise of cortisol compatible to non-classic 11OHD. Treatment with hydrocortisone $\left(10 \mathrm{mg} / \mathrm{m}^{2}\right.$ per day) was initiated. At the age of 7.1 years, breast development started and therapy with triptorelin was started without performing further hormonal tests because of precocious puberty secondary to adrenal androgen excess.

The brother of patient 4 was first seen at the age of 8 months. Auxological data were height $68 \mathrm{~cm}(-1.1$ SDS) (20), weight $9 \mathrm{~kg}$ and BMI $19.5 \mathrm{~kg} / \mathrm{m}^{2}$ (+1.1 SDS) (17). The androgen metabolites in urine were within the normal range for age. At the age of 16 months there were still no signs of virilisation, height $82.2 \mathrm{~cm}(+0.4$ SDS) and growth rate accelerated with $20.3 \mathrm{~cm} /$ year within the last 8 months (+1.5 SDS). Bone age was not analysed yet.

\section{Sequence analysis of the CYP11B1 gene}

The molecular analysis of the CYP11B1 gene was carried out after receiving informed consent from patients and/or legal guardian for genetic studies. Genomic DNA was prepared from peripheral blood leukocytes and amplification of exons 1-9 of the CYP11B1 gene was carried out as described previously $(22,23)$. Direct DNA sequencing and analysis of the coding region of the CYP11B1 gene was done as described previously (23). Sequence variants were designated according to the recommendations of the Human Genome Variation Society (www.hgvs.org/ rec.html) using the GenBank reference sequences NC_000008.10 (CYP11B1 g.DNA), NM_000497 (CYP11B1 c.DNA) and NP_000488.3 (CYP11B1 p.protein).

\section{Transient transfection assay}

Each mutation was introduced into a CYP11B1-pcDNA3.1 expression vector construct (kindly provided by Prof. $\mathrm{R}$ Bernhardt, Institute of Biochemistry, University des Saarlandes, Saarbrücken, Germany) by site-directed mutagenesis as described previously $(24,25)$. In vitro transient transfection assay was performed in triplicates using the HEK293 cell line thrice. The cells were transfected with each pcDNA3.1-CYP11B1 mutant constructs with additional transfection of adrenodoxin (pECE- $A D X)$, Adx reductase (pECE- $A D R$ ) expression vectors (kindly provided by Prof. W L Miller, Department of Pediatrics, University of California, San Francisco, CA, USA) and pRK-TK (Promega) coding for Renilla luciferase as it was described in our previous paper (25). The kinetic constants of CYP11B1 in intact HEK293 cells were determined $48 \mathrm{~h}$ after transfection. The cells were incubated in triplicates for 270 min at $37^{\circ} \mathrm{C}$ with $1 \mathrm{ml}$ DMEM medium containing $0.1,0.25,0.5,1,2$, and $4 \mu \mathrm{mol} / 1 \mathrm{DOC}$ and $\mathrm{S}$ in parallel with $10 \mathrm{mM}$ NADPH (Sigma-Aldrich). The steroid hormones DOC, B, S and F were simultaneously determined in the cell culture supernatant using an UPLC-MS/MS method as described previously $(25,26,27)$. Western blot analysis was carried out to ensure the expression and translation of WT and mutant proteins as described previously $(24,25,28)$.

All assays were performed in at least three independent triplicate experiments, and data are presented as mean \pm s.D. Kinetic parameters were established by nonlinear regression using the Michaelis-Menten equation to determine the Michaelis-Menten constant $\left(K_{\mathrm{m}}\right)$ and maximum velocity $\left(V_{\max }\right)$. Catalytic efficiency was defined as the ratio $V_{\max } / K_{\mathrm{m}}$ expressed as percentage of WT. The 11-hydroxylase activity of the mutants was expressed as a percentage of substrate conversion in picomole per milligram of total protein per minute, defining CYP11B1 WT activity as $100 \%$ after correction for total protein with Renilla luciferase activity. Enzyme kinetic parameters and enzymatic activity were calculated using the GraphPad Prism Software, version 5.0 (GraphPad, Inc., San Diego, CA, USA).

\section{Molecular modelling}

We used a fold recognition algorithm to show that the human CYP11B1 sequence is compatible with the architecture of the enzyme family (ProHit package, ProCeryon Biosciences $\mathrm{GmbH}$, Salzburg, Austria). The template structure with the highest score of the pair potential was the X-ray structure of the cytochrome CYP11A1 (PDB accession code: $3 \mathrm{MZS}$ ) and served as the template for the three-dimensional model of CYP11B1. According to the alignment obtained by the fold recognition procedure, amino acid residues were exchanged in the template. Insertions and deletions in CYP11B1 were modelled using a database search approach included in the software package WHATIF. The structural representation was generated with the Ribbons Software (Avatar Software AB, Stockholm, Sweden) as described previously (29). 


\section{Results}

\section{Sequence analysis of the CYP11B1 gene}

Patient 1 showed a novel homozygous guanine deletion at cDNA position 372 (c.372delG) in exon 2 of the CYP11B1 gene, resulting in a frameshift and a premature stop codon (p.His125Thrfs*8). Patient 2 showed the identical homozygous deletion c.372delG. Parents were not available for analysis; therefore, a heterogeneous deletion of the CYP11B1 gene cannot be ruled out. Genetic analysis in patient 3 depicted a novel homozygous duplication of six bases in exon 8, c.1387_1392dupCTGCTG, causing a duplication of two leucines in frame p.Leu463 Leu464dup. The CYP11B1 gene analysis revealed that patient 4 was compound heterozygous for the novel mutation c.372delG (p.His125Thrfs*8) inherited from the mother and the novel mutation c.449C $>$ T (p.Ser150Leu) located in exon 3 inherited from the father (Fig. 2).

\section{In vitro functional 11-hydroxylase assays}

The three novel CYP11B1 mutations were functionally analysed using transiently transfected HEK293 cells measuring the conversion of DOC to B and S to F. The two mutations detected in patients with 11OHD (p.His125Thrfs*8 and p.Leu463_Leu464dup) had no residual enzymatic activity. The mutation p.Ser150Leu detected with non-classic 11OHD showed only partial 11-hydroxylase impairment with a reduced activity of $19.2 \pm 1.4 \%$ (mean \pm s.D.) and $14.7 \pm 0.5 \%$ (mean \pm s.D.) for the conversion to $\mathrm{B}$ and $\mathrm{F}$ compared with WT respectively. Determination of kinetic constants showed similar $K_{\mathrm{m}}$ values for both $B$ and $F$ production with significantly impaired $V_{\max }$ compared with the WT (Fig. 3).

Western blot analysis demonstrated that all mutations apart from the p.His125Thrfs ${ }^{\star} 8$ had translation efficiency similar to WT. The mutant p.His $125 \mathrm{Thrfs}^{\star} 8$ was not detectable by western blotting either due to the loss of the antibody binding site or due to nonsense-mediated mRNA or protein decay (Supplementary Fig. 1, see section on supplementary data given at the end of this article).

\section{Molecular modelling}

The frameshift mutation p.His $125 \mathrm{Thrfs}^{*} 8$ terminates the translation at the B-C loop of the protein (30). By this, all relevant enzyme structures including the substrate recognitions sides and haeme-binding sites are not present, resulting in a complete loss of function $(31,32)$. The variation p.Leu463_Leu464dup is located in the amino terminal L-helix. Two leucines are inserted in a leucine-rich part of the L-helix carrying four leucines. The L-helix is involved in haeme binding as well as in interactions with redox partners (30). The distal L-helix forms parts of the protein's surface. The residue p.Ser 150 is located in the C-D loop connecting the C-helix with the D-helix (Fig. 4).

\section{Discussion}

In the present study, we have functionally characterised three novel CYP11B1 mutations detected in three families. The p.Leu463_Leu464dup and p.Ser150Leu mutations were unique for the studied families. On the contrary, the p.His125Thrfs*8 mutation was detected in both Moroccan and Turkish families where there is no known relationship. Reported CYP11B1 mutations are p.Arg448Cys $(33,34)$, p.Trp116Cys, p.Leu299Pro (2), p.Leu489Ser (15), Glu338term (35) and p.Asn394 Argfs*74, p.Trp318Thr, p.Arg43Gln and Ala259Asp in the Turkish population IVS5 $+2 \mathrm{~T}>\mathrm{G}$, p.Gly446Val (36) and p.Arg448Cys (22) in the Moroccan population. The elevated frequency of 11OHD in Morocco and Turkey is most likely due to the higher rate of consanguineous marriages producing an enrichment of recessively inherited diseases (37). The prevalence of consanguinity in Morocco reported to date varies between $20-28$ and $59.1 \%$ in patients suffering from autosomal recessive diseases (38). In Turkey, around $20 \%$ of marriages are consanguineous (39).

In vitro 11-hydroxylase activity of $<5 \%$ can be considered severe and is most often associated with classic 11OHD $(7,24,40)$. The patients 1 and 2 carrying a completely inactivating mutation (p.His125Thrfs ${ }^{\star} 8$ ) of the CYP11B1 gene show a typical classical 11OHD phenotype with highly elevated steroids hormones, prenatal virilisation of the external genitalia in females and macrogenitosomia in males (5). Neither patients showed obvious signs of hypertension. The latest clinical assessment revealed that hydrocortisone treatment with doses above the recommended has not been effective enough to normalise steroid hormone levels in either patient, most likely because of poor adherence to the treatment. This demonstrates the necessity for long-term follow-up of the patients by experienced physicians, which is obviously difficult in rural Turkey. The mutation p.His125Thrfs has a comparable effect on the protein structure and function with the mutant c.358-362dup 


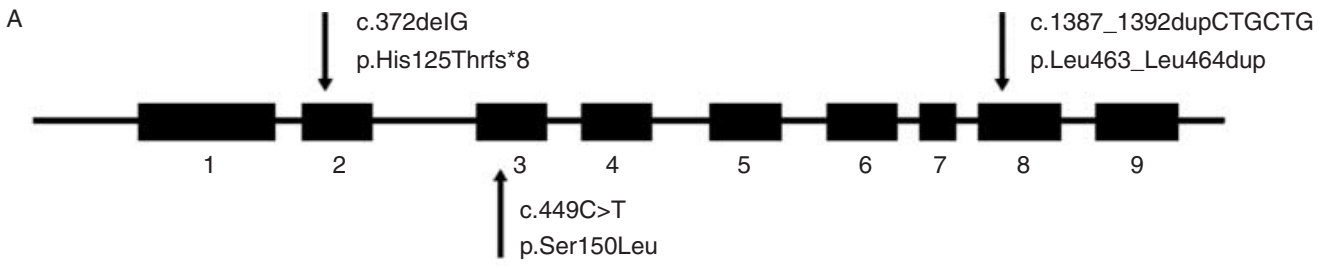

B Patients 1 and 2
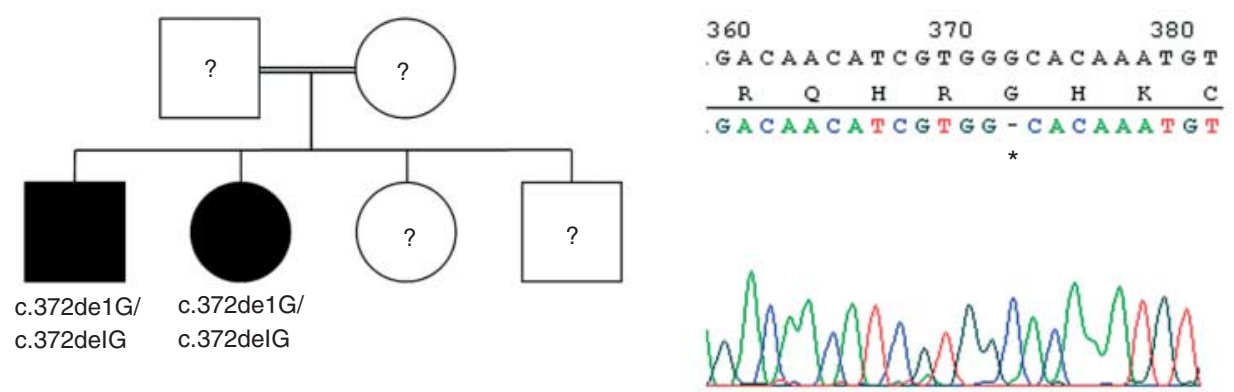

Patient 3

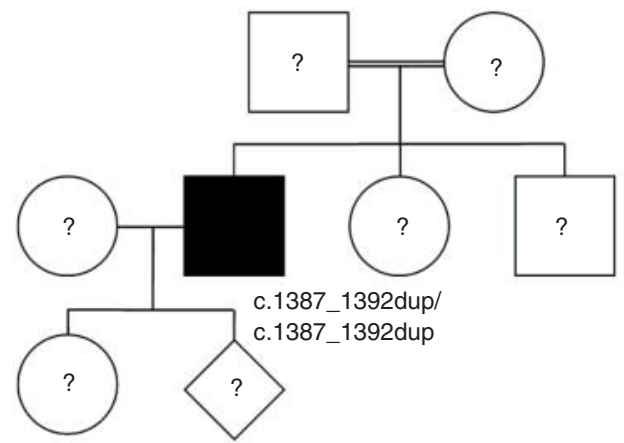

$1380 \quad 1390$

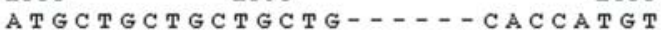

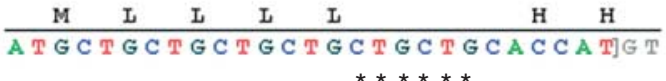

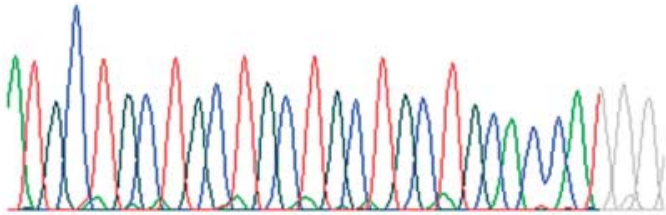

Patient 4
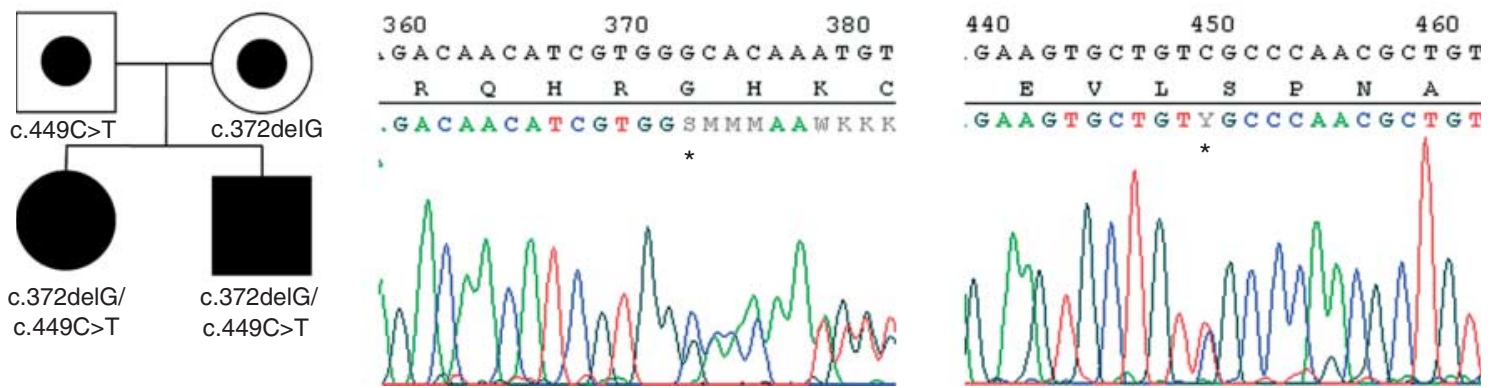

\section{Figure 2}

Molecular genetic analysis of the CYP11B1 gene. (A) Schematic localisation of the mutations. (B) Pedigrees of the patients from three unrelated families with electropherograms of the mutations. Star indicates mutated nucleotides. Question marks indicate individuals not available for genetic analysis.

(p.H122Dfs*13) detected in a patient with a classic 11OHD phenotype described previously by Skinner et al. (41).

Patient 3, carrying a complete loss-of-function mutation (p.Leu463_Leu464dup) on the CYP11B1 gene, came to clinical attention with premature pubarche in childhood. He was short statured due to insufficient treatment during childhood and adolescence. He developed bilateral TART which is the most important cause of infertility in men with $\mathrm{CAH}$ to 21-hydroxylase deficiency (42). Ectopically located adrenal tissues 

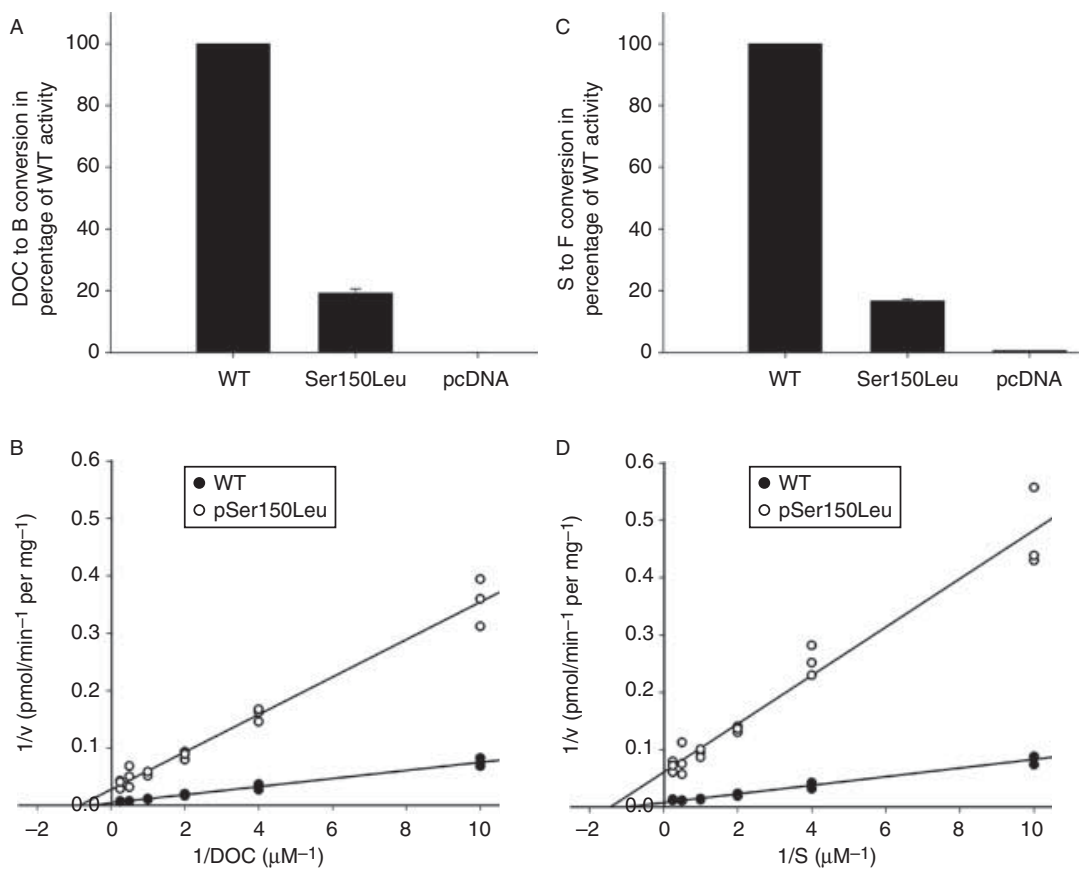

\begin{tabular}{c|c|c}
$\mathrm{DOC} \rightarrow \mathrm{B}$ & $\mathrm{WT}$ & p.Ser150Leu \\
\hline $\mathrm{V}_{\max }$ & $200 \pm 12$ & $34 \pm 4$ \\
\hline $\mathrm{K}_{\mathrm{m}}$ & $1.2 \pm 0.8$ & $1.0 \pm 0.3$ \\
\hline $\mathrm{V}_{\text {max }} / \mathrm{K}_{\mathrm{m}}$ & 167 & 34 \\
\hline $\begin{array}{c}\text { Catalytic } \\
\text { efficiency (\%) }\end{array}$ & 100 & 20
\end{tabular}

\begin{tabular}{c|c|c}
$\mathrm{S} \rightarrow \mathrm{F}$ & $\mathrm{WT}$ & p.Ser150Leu \\
\hline $\mathrm{V}_{\max }$ & $106 \pm 6$ & $17 \pm 2$ \\
\hline $\mathrm{K}_{\mathrm{m}}$ & $0.6 \pm 0.1$ & $0.7 \pm 0.8$ \\
\hline $\mathrm{V}_{\text {max }} / \mathrm{K}_{\mathrm{m}}$ & 176 & 24 \\
\hline $\begin{array}{c}\text { Catalytic } \\
\text { efficiency (\%) }\end{array}$ & 100 & 14
\end{tabular}

\section{Figure 3}

Residual 11-hydroxylase activity of the CYP11B1 variants assessed in transiently transfected HEK293 cells co-expressing human WT or mutant CYP11B1 with human Adx reductase and Adx respectively. (A) Corticosterone production of the mutant expressed as percentage of WT activity which is defined as $100 \%$. Error bars represent the mean \pm s.D. (B) Lineweaver-Burk plot of 11-hydroxylase activity converting DOC to

usually regress with advancing age except in $\mathrm{CAH}$ patients in whom low levels of cortisol induce ACTH secretion and hyperplasia of dispersed adrenal tissue (43). The presence of adrenal rests within the testes of adult males with classic 21-hydroxylase $\mathrm{CAH}$ is more frequent in the salt-wasting form and is associated with a higher risk for infertility (44). 11OHD patients with TART are rare. Up to our knowledge, only nine cases are presented in the literature so far $(43,45,46,47,48)$. This is most likely due to the smaller incidence of CAH due to 11-hydroxylase deficiency. All reported cases were poorly compliant to treatment. However, the idea that poor control may lead to a higher risk of TART was just recently refuted in 21-hydroxylase deficiency $(49,50)$. Therefore, the findings in $11 \mathrm{OHD}$ may be a collection bias. In the patient, the TART located in the right testis was removed because of its size and the difficulty to distinguish it from a Leydig cell tumour during follow-up (51). TART cells showed eosinophilic cytoplasm with neither lipochrome pigments nor Reinke crystalloids (Fig. 1) $(47,52)$. The tumour on the left is under control with prednisolone treatment. Whether surgery has had a positive effect on the testicular function or whether resuming prednisolone treatment led to fertility remains unclear. TART surgery in 21-hydroxylase deficiency has no proven effect on fertility (53). 


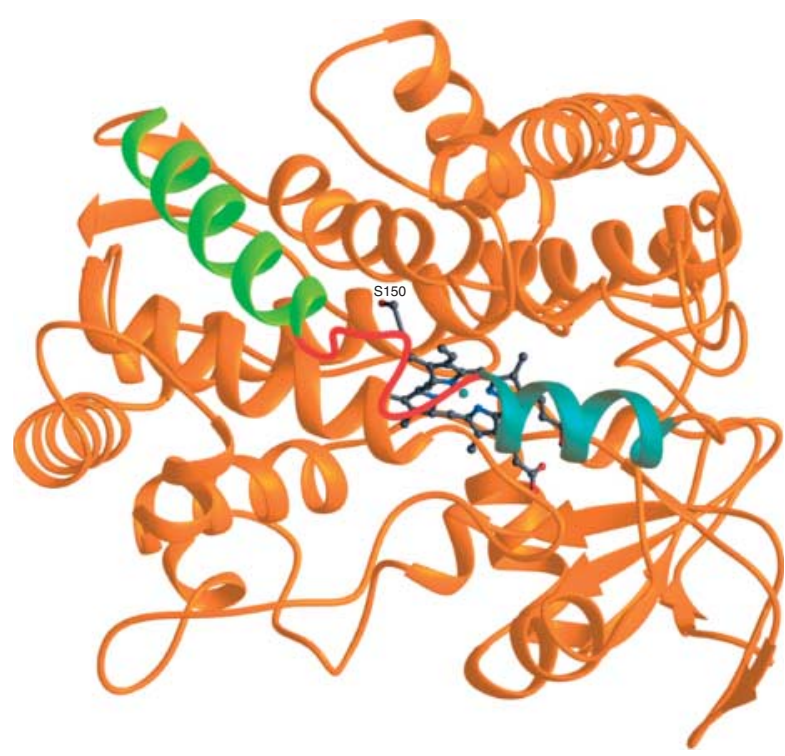

\section{Figure 4}

Ribbon representation of the three-dimensional molecular model of CYP11B1. Helix C, the CD-loop and helix D are coloured light blue, red and light green respectively. The side chain of residue Ser150 located in the C-D loop is depicted.

The variation p.Leu463_Leu464dup detected in patient 3 is located in the amino terminal L-helix. Two leucines are inserted in a leucine-rich part of the L-helix carrying four leucines. The L-helix is involved in haeme binding as well as in interactions with redox partners (30). The distal L-helix forms parts of the protein's surface. As four residues are needed for a full helical turn, the addition of two residues will produce an additional half turn of the helix, leading to a displacement of the proximal part of the helix and disturbance of substrate binding and electron flux, or interference with the binding of redox partners due to changes in the protein surface. Both possibilities will result in a complete loss of function. Interestingly, Geley et al. described a patient with classic $110 H D$, caused by a duplication of a single leucine at the identical position. This variant also caused a complete loss of 11-hydroxylase activity (7).

Patient 4 showed clinical signs compatible with nonclassic CAH (25). The novel mutation p.Ser150Leu detected in this patient had a residual activity of $19.2 \%$ of the WT. By this, it is comparable with the previously described mutations associated with non-classic 11OHD. Interestingly, only 12 mutations causing non-classic 11 OHD have been described so far $(8,10,25,54)$. This is most likely due to the overall rarity of $110 \mathrm{HD}$. However, the increasing number of reports on affected patients should increase the awareness for non-classic 11OHD. The residual activity of mutations associated with non-classic 110 HD ranged from 9 to $40 \%$ of WT activity, which is well comparable with the residual activity of mutations in the CYP21A2 gene causing non-classic 21-hydroxylase deficiency (55). The residue p.Ser150 is located in the C-D loop connecting the C-helix with the D-helix of the CYP11B1 protein (Fig. 4). This loop is located at the surface of the molecule. The change to p.Leu150 does not lead to obvious steric problems with neighbouring residues in silico. However, the exchange of the polar serine by the hydrophobic leucine leads to a change in the surface properties of the molecule. Since the adjacent D-helix is part of the redox partner interaction side, the mutation may induce a decrease in electron flux which is consistent with the observed reduction of $V_{\max }(30,32)$.

In conclusion, we have shown the inactivating nature of two novel CYP11B1 mutations in classic 11OHD in addition to one variant with residual activity associated with non-classic $110 \mathrm{HD}$. The analyses of in vitro enzyme function broaden our understanding of CYP11B1 function relationships and help to counsel families as the severity of the clinical disease expression can be estimated. The condition of non-classic $110 \mathrm{HD}$ is a rare disease but should not be missed in the differential diagnosis of hyperandrogenism.

\section{Supplementary data}

This is linked to the online version of the paper at http://dx.doi.org/10.1530/ EJE-13-0737.

Declaration of interest

The authors declare that there is no conflict of interest that could be perceived as prejudicing the impartiality of the research reported.

\section{Funding}

This study was partially supported by an unrestricted visiting scholarship grant from the European Society for Paediatric Endocrinology to S Polat.

\section{Acknowledgements}

The authors are grateful to Rita Bernhardt (Institute of Biochemistry, Universität des Saarlandes, Saarbrücken, Germany) for providing the CYP11B1 CDNA, Walter L Miller (Department of Pediatrics, University of California, San Francisco, CA, USA) for providing the Adx and Adr CDNA and Hiroshi Takemori (Department of Molecular Physiological Chemistry, Osaka University Medical School, Osaka, Japan) for providing the antihumanCYP11B rabbit antiserum. We appreciate the expert technical assistance of Tanja Stampe and Gisela Hohmann.
} 


\section{References}

1 White PC \& Speiser PW. Steroid $11 \beta$-hydroxylase deficiency and related disorders. Endocrinology and Metabolism Clinics of North America 199423 325-339.

2 Krone N, Riepe FG, Gotze D, Korsch E, Rister M, Commentz J, Partsch CJ, Grotzinger J, Peter M \& Sippell WG. Congenital adrenal hyperplasia due to 11-hydroxylase deficiency: functional characterization of two novel point mutations and a three-base pair deletion in the CYP11B1 gene. Journal of Clinical Endocrinology and Metabolism 2005 90 3724-3730. (doi:10.1210/jc.2005-0089)

3 White PC, Curnow KM \& Pascoe L. Disorders of steroid 11 $\beta$-hydroxylase isozymes. Endocrine Reviews 199415 421-438.

4 New MI \& White PC. Genetic disorders of steroid hormone synthesis and metabolism. Baillière's Clinical Endocrinology and Metabolism 19959 525-554. (doi:10.1016/S0950-351X(95)80587-7)

5 Zachmann M, Tassinari D \& Prader A. Clinical and biochemical variability of congenital adrenal hyperplasia due to $11 \beta$-hydroxylase deficiency. A study of 25 patients. Journal of Clinical Endocrinology and Metabolism 198356 222-229. (doi:10.1210/jcem-56-2-222)

6 Stenson PD, Ball E, Howells K, Phillips A, Mort M \& Cooper DN. Human Gene Mutation Database: towards a comprehensive central mutation database. Journal of Medical Genetics 200845 124-126. (doi:10.1136/ jmg.2007.055210

7 Geley S, Kapelari K, Johrer K, Peter M, Glatzl J, Vierhapper H, Schwarz S, Helmberg A, Sippell WG, White PC et al. CYP11B1 mutations causing congenital adrenal hyperplasia due to $11 \beta$-hydroxylase deficiency. Journal of Clinical Endocrinology and Metabolism 199681 2896-2901.

8 Parajes S, Loidi L, Reisch N, Dhir V, Rose IT, Hampel R, Quinkler M, Conway GS, Castro-Feijoo L, Araujo-Vilar D et al. Functional consequences of seven novel mutations in the CYP11B1 gene: four mutations associated with nonclassic and three mutations causing classic $11\{\beta\}$-hydroxylase deficiency. Journal of Clinical Endocrinology and Metabolism 201095 779-788. (doi:10.1210/jc.2009-0651)

9 Chabre O, Portrat-Doyen S, Vivier J, Morel Y \& Defaye G. Two novel mutations in splice donor sites of CYP11B1 in congenital adrenal hyperplasia due to 11ß-hydroxylase deficiency. Endocrine Research 2000 26 797-801. (doi:10.3109/07435800009048602)

10 Joehrer K, Geley S, Strasser-Wozak EM, Azziz R, Wollmann HA, Schmitt K, Kofler R \& White PC. CYP11B1 mutations causing nonclassic adrenal hyperplasia due to $11 \beta$-hydroxylase deficiency. Human Molecular Genetics 19976 1829-1834. (doi:10.1093/hmg/6.11.1829)

11 Speiser PW \& White PC. Congenital adrenal hyperplasia. New England Journal of Medicine 2003349 776-788. (doi:10.1056/NEJMra021561)

12 Wu C, Zhou Q, Wan L, Ni L, Zheng C, Qian Y \& Jin J. Novel homozygous p.R454C mutation in the CYP11B1 gene leads to $11 \beta$-hydroxylase deficiency in a Chinese patient. Fertility and Sterility 20111122 e1123-e1126.

13 Krone N, Grotzinger J, Holterhus PM, Sippell WG, Schwarz HP \& Riepe FG. Congenital adrenal hyperplasia due to 11-hydroxylase deficiency - insights from two novel CYP11B1 mutations (p.M92X, p.R453Q). Hormone Research 200972 281-286. (doi:10.1159/ 000245930)

14 Sonino N, Levine LS, Vecsei P \& New MI. Parallelism of $11 \beta$ - and 18-hydroxylation demonstrated by urinary free hormones in man. Journal of Clinical Endocrinology and Metabolism 198051 557-560. (doi:10.1210/jcem-51-3-557)

15 Peters CJ, Nugent T, Perry LA, Davies K, Morel Y, Drake WM, Savage MO \& Johnston LB. Cosegregation of a novel homozygous CYP11B1 mutation with the phenotype of non-classical congenital adrenal hyperplasia in a consanguineous family. Hormone Research 200767 189-193. (doi:10.1159/000097244)

16 Gokcay G, Furman A \& Neyzi O. Updated growth curves for Turkish children aged 15 days to 60 months. Child: Care, Health and Development 200834 454-463. (doi:10.1111/j.1365-2214.2008.00813.x)
17 Kondolot M, Balci E, Ozturk A, Mazicioglu MM, Hatipoglu N, Kurtoglu S \& Ustunbas HB. Body mass index percentiles for Turkish children aged 0-84 months. Annals of Human Biology 201138 676-680. (doi:10.3109/03014460.2011.605800)

18 Tumer N, Yalcinkaya F, Ince E, Ekim M, Kose K, Cakar N, Kara N, Ozkaya N, Ensari C \& Onder S. Blood pressure nomograms for children and adolescents in Turkey. Pediatric Nephrology 199913 438-443. (doi:10.1007/s004670050636)

19 Cinaz P, Yesilkaya E, Onganlar YH, Boyraz M, Bideci A, Camurdan O \& Karaoglu AB. Penile anthropometry of normal prepubertal boys in Turkey. Acta Paediatrica 2012101 e33-e36. (doi:10.1111/j.1651-2227. 2011.02386.x)

20 Neyzi O, Furman A, Bundak R, Gunoz H, Darendeliler F \& Bas F. Growth references for Turkish children aged 6 to 18 years. Acta Paediatrica 2006 95 1635-1641. (doi:10.1080/08035250600652013)

21 Ozturk A, Mazicioglu MM, Hatipoglu N, Budak N, Keskin G, Yazlak Z, Balci N, Yildiz H, Yildiz K, Ustunbas HB et al. Reference body mass index curves for Turkish children 6 to 18 years of age. Journal of Pediatric Endocrinology \& Metabolism 200821 827-836. (doi:10.1515/JPEM.2008. 21.9.827)

22 White PC, Dupont J, New MI, Leiberman E, Hochberg Z \& Rosler A. A mutation in CYP11B1 (Arg-448_-His) associated with steroid $11 \beta$-hydroxylase deficiency in Jews of Moroccan origin. Journal of Clinical Investigation 199187 1664-1667. (doi:10.1172/JCI115182)

23 Naiki Y, Kawamoto T, Mitsuuchi Y, Miyahara K, Toda K, Orii T, Imura H $\&$ Shizuta Y. A nonsense mutation (TGG [Trp116] $\rightarrow$ TAG [Stop]) in CYP11B1 causes steroid 11ß-hydroxylase deficiency. Journal of Clinical Endocrinology and Metabolism 199377 1677-1682.

24 Krone N, Grischuk Y, Muller M, Volk RE, Grotzinger J, Holterhus PM, Sippell WG \& Riepe FG. Analyzing the functional and structural consequences of two point mutations (P94L and A368D) in the CYP11B1 gene causing congenital adrenal hyperplasia resulting from 11-hydroxylase deficiency. Journal of Clinical Endocrinology and Metabolism 200691 2682-2688. (doi:10.1210/jc.2006-0209)

25 Menabo S, Polat S, Baldazzi L, Kulle AE, Holterhus PM, Grotzinger J, Fanelli F, Balsamo A \& Riepe FG. Congenital adrenal hyperplasia due to 11- $\beta$-hydroxylase deficiency: functional consequences of four CYP11B1 mutations. European Journal of Human Genetics 2013. (doi:10.1038/ ejhg.2013.197)

26 Kulle AE, Riepe FG, Melchior D, Hiort O \& Holterhus PM. A novel ultrapressure liquid chromatography tandem mass spectrometry method for the simultaneous determination of androstenedione, testosterone, and dihydrotestosterone in pediatric blood samples: age- and sex-specific reference data. Journal of Clinical Endocrinology and Metabolism 201095 2399-2409. (doi:10.1210/jc.2009-1670)

27 Kulle AE, Welzel M, Holterhus PM \& Riepe FG. Principles and clinical applications of liquid chromatography - tandem mass spectrometry for the determination of adrenal and gonadal steroid hormones. Journal of Endocrinological Investigation 201134 702-708.

28 Clark BJ, Wells J, King SR \& Stocco DM. The purification, cloning, and expression of a novel luteinizing hormone-induced mitochondria protein in MA-10 mouse Leydig tumor cells. Characterization of the steroidogenic acute regulatory protein (StAR). Journal of Biological Chemistry $199426928314-28322$.

29 Kraulis PJ. Molscript - a program to produce both detailed and schematic plots of protein structures. Journal of Applied Crystallography 199124 946-950. (doi:10.1107/S0021889891004399)

30 Otyepka M, Skopalik J, Anzenbacherova E \& Anzenbacher P. What common structural features and variations of mammalian P450s are known to date? Biochimica et Biophysica Acta 20071770 376-389. (doi:10.1016/j.bbagen.2006.09.013)

31 Gotoh O. Substrate recognition sites in cytochrome-P450 family-2 (Cyp2) proteins inferred from comparative analyses of amino-acid and coding nucleotide-sequences. Journal of Biological Chemistry 1992267 83-90. 
32 Robins T, Carlsson J, Sunnerhagen M, Wedell A \& Persson B. Molecular model of human CYP21 based on mammalian CYP2C5: structural features correlate with clinical severity of mutations causing congenital adrenal hyperplasia. Molecular Endocrinology 200620 2946-2964. (doi:10.1210/me.2006-0172)

33 Cingoz S, Ozkan B, Doneray H \& Sakizli M. Familial pericentric inversion chromosome 3 and R448C mutation of CYP11B1 gene in Turkish kindred with $11 \beta$-hydroxylase deficiency. Journal of Endocrinological Investigation $200730285-291$.

34 Helmberg A, Ausserer B \& Kofler R. Frame shift by insertion of 2 basepairs in codon 394 of CYP11B1 causes congenital adrenal hyperplasia due to steroid $11 \beta$-hydroxylase deficiency. Journal of Clinical Endocrinology and Metabolism 199275 1278-1281.

35 Zhu YS, Cordero JJ, Can S, Cai LQ, You XK, Herrera C, DeFillo-Ricart M, Shackleton C \& Imperato-McGinley J. Mutations in CYP11B1 gene: phenotype-genotype correlations. American Journal of Medical Genetics. Part A 2003 122A 193-200. (doi:10.1002/ajmg.a.20108)

36 Chabraoui L, Abid F, Menassa R, Gaouzi A, El Hessni A \& Morel Y. Three novel CYP11B1 mutations in congenital adrenal hyperplasia due to steroid 11ß-hydroxylase deficiency in a Moroccan population. Hormone Research in Paediatrics 201074 182-189. (doi:10.1159/000281417)

37 Hussain R, Bittles AH \& Sullivan S. Consanguinity and early mortality in the Muslim populations of India and Pakistan. American Journal of Human Biology 200113 777-787. (doi:10.1002/ajhb.1124)

38 Jaouad IC, Elalaoui SC, Sbiti A, Elkerh F, Belmahi L \& Sefiani A. Consanguineous marriages in Morocco and the consequence for the incidence of autosomal recessive disorders. Journal of Biosocial Science 200941 575-581. (doi:10.1017/S0021932009003393)

39 Alper OM, Erengin H, Manguoglu AE, Bilgen T, Cetin Z, Dedeoglu N \& Luleci G. Consanguineous marriages in the province of Antalya, Turkey. Annales de Génétique 200447 129-138.

40 Kuribayashi I, Nomoto S, Massa G, Oostdijk W, Wit JM, Wolffenbuttel BHR, Shizuta Y \& Honke K. Steroid 11- $\beta$-hydroxylase deficiency caused by compound heterozygosity for a novel mutation, p.G314R, in one CYP11B1 allele, and a chimeric CYP11B2/CYP11B1 in the other allele. Hormone Research 200563 284-293. (doi:10.1159/ 000087074)

41 Skinner CA \& Rumsby G. Steroid 11ß-hydroxylase deficiency caused by a five base pair duplication in the CYP11B1 gene. Human Molecular Genetics 19943 377-378. (doi:10.1093/hmg/3.2.377)

42 Claahsen-van der Grinten HL, Hermus AR \& Otten BJ. Testicular adrenal rest tumours in congenital adrenal hyperplasia. International Journal of Pediatric Endocrinology 20092009 624823. (doi:10.1186/ 1687-9856-2009-624823)

43 Karnak I, Senocak ME, Gogus S, Buyukpamukcu N \& Hicsonmez A. Testicular enlargement in patients with 11-hydroxylase deficiency. Journal of Pediatric Surgery 199732 756-758. (doi:10.1016/S00223468(97)90027-0)

44 Cabrera MS, Vogiatzi MG \& New MI. Long term outcome in adult males with classic congenital adrenal hyperplasia. Journal of Clinical Endocrinology and Metabolism 200186 3070-3078.
45 Srikanth MS, West BR, Ishitani M, Isaacs H Jr, Applebaum H \& Costin G. Benign testicular tumors in children with congenital adrenal hyperplasia. Journal of Pediatric Surgery 199227 639-641. (doi:10.1016/00223468(92)90466-K)

46 Ghazi AA, Hadayegh F, Khakpour G, Azizi F \& Melby JC. Bilateral testicular enlargement due to adrenal remnant in a patient with $\mathrm{C} 11$ hydroxylase deficiency congenital adrenal hyperplasia. Journal of Endocrinological Investigation 200326 84-87.

47 Mirzaei MR, Rezvanian H, Siavash M, Parham M \& Mahzouni P. A patient with refractory testicular adrenal rest tumour in the setting of cyp11b1 deficiency congenital adrenal hyperplasia. BMJ Case Reports 2009. (doi:10.1136/bcr.06.2008.0280)

48 Charfi N, Kamoun M, Feki Mnif M, Mseddi N, Mnif F, Kallel N, Ben Naceur B, Rekik N, Fourati H, Daoud E et al. Leydig cell tumor associated with testicular adrenal rest tumors in a patient with congenital adrenal hyperplasia due to $11 \beta$-hydroxylase deficiency. Case Reports in Urology 20122012 648643. (doi:10.1155/2012/648643)

49 Bercovici JP, Fiet J, Gibault L, Volant A, Abalain JH, Floch HH, Sonnet E $\&$ Fournier G. Testicular adrenal rest tumours in salt wasting congenital adrenal hyperplasia (in vivo and in vitro studies). Journal of Steroid Biochemistry and Molecular Biology 200593 67-72. (doi:10.1016/ j.jsbmb.2004.10.023)

50 Reisch N, Rottenkolber M, Greifenstein A, Krone N, Schmidt H, Reincke M, Schwarz HP \& Beuschlein F. Testicular adrenal rest tumors develop independently of long-term disease control: a longitudinal analysis of 50 adult men with congenital adrenal hyperplasia due to classic 21-hydroxylase deficiency. Journal of Clinical Endocrinology and Metabolism 201398 E1820-E1826. (doi:10.1210/jc.2012-3181)

51 Rich MA \& Keating MA. Leydig cell tumors and tumors associated with congenital adrenal hyperplasia. Urologic Clinics of North America 2000 27 519-528 x. (doi:10.1016/S0094-0143(05)70099-9)

52 Mostofi FK, Davis J Jr \& Rehm S. Tumours of the testis. IARC Scientific Publications 1994111 407-429.

53 Claahsen-van der Grinten HL, Otten BJ, Takahashi S, Meuleman EJ, Hulsbergen-van de Kaa C, Sweep FC \& Hermus AR. Testicular adrenal rest tumors in adult males with congenital adrenal hyperplasia: evaluation of pituitary-gonadal function before and after successful testis-sparing surgery in eight patients. Journal of Clinical Endocrinology and Metabolism 200792 612-615. (doi:10.1210/jc.2006-1311)

54 Reisch N, Hogler W, Parajes S, Rose IT, Dhir V, Gotzinger J, Arlt W \& Krone N. A diagnosis not to be missed: non-classic steroid $11 \beta$-hydroxylase deficiency presenting with premature adrenarche and hirsutism. Journal of Clinical Endocrinology and Metabolism 201398 E1620-E1625. (doi:10.1210/jc.2013-1306)

55 White PC \& Speiser PW. Congenital adrenal hyperplasia due to 21-hydroxylase deficiency. Endocrine Reviews 200021 245-291.

56 Kulle AE, Welzel M, Holterhus PM \& Riepe FG. Implementation of a liquid chromatography tandem mass spectrometry assay for eight adrenal C-21 steroids and pediatric reference data. Hormone Research in Paediatrics 201379 22-31. (doi:10.1159/000346406)

Received 8 September 2013

Revised version received 15 December 2013

Accepted 14 February 2014 